\title{
Recommendations for the practice of breastfeeding in the COVID-19 pandemic: integrative review
}

Recomendações para a prática do aleitamento materno na pandemia de COVID-19: uma revisão integrativa

Recomendaciones para la práctica de la lactancia materna en la pandemia de COVID-19: revisión integradora 


\begin{abstract}
Objective: to analyze the general recommendations for the practice of breastfeeding in the face of infection by the new coronavirus. Method: integrative literature review, carried out in the LILACS and Pubmed databases, from March to May 2020. The searches took place with the following combinations of descriptors "Coronavirus", "Lactation" and "Breastfeeding". The limitation regarding the year of publication of the articles during the searches carried out was from 2019 to 2020. Results: the search in the data sources allowed the inclusion of ten articles, two from Brazilian journals, found in the LILACS database, and eight of international origin, selected in the PubMed database. Conclusion: From this review, it became evident that most studies addressed the recommendation to maintain the practice of breastfeeding in women with COVID-19. These studies reinforce the importance of counseling, the necessary care during the act of breastfeeding, in addition to recognizing the benefits of breastfeeding. The large number of research on the subject defends and favors breastfeeding for women suspected or diagnosed with COVID-19, which limits the discussion with similar articles.
\end{abstract}

Keywords: COVID-19; Coronavirus; Lactation; Breast feeding.

\title{
Resumo
}

Objetivo: analisar as recomendações gerais para a prática do aleitamento materno diante da infecção pelo novo coronavírus. Método: revisão integrativa da literatura, realizada nas bases de dados LILACS e Pubmed, no período de março a maio de 2020. As buscas ocorreram com a combinação dos descritores "Coronavirus", "Lactation" e "Breastfeeding". A limitação quanto ao ano de publicação dos artigos durante as buscas realizadas foi de 2019 a 2020. Resultados: a busca nas fontes de dados permitiu a inclusão de dez artigos, dois de periódicos brasileiros, encontrados na base de dados LILACS, e oito de origem internacional, selecionada na base de dados PubMed. Conclusão: a partir desta revisão, ficou evidente que a maioria dos estudos abordou a recomendação de manter a prática do aleitamento materno por mulheres com COVID-19. Esses estudos reforçam a importância do aconselhamento, dos cuidados necessários durante o ato de amamentar, além de reconhecer os benefícios da amamentação. O grande número de pesquisas sobre o tema defende e favorece o aleitamento materno por mulheres suspeitas ou diagnosticadas com COVID-19, o que limita a discussão com artigos semelhantes.

Palavras-chave: COVID-19; Coronavírus; Lactação; Aleitamento materno.

\section{Resumen}

Objetivo: analizar las recomendaciones generales para la práctica de la lactancia materna ante la infección por el nuevo coronavirus. Método: revisión integrativa de la literatura, realizada en las bases de datos LILACS y Pubmed, de marzo a mayo de 2020. Las búsquedas se realizaron con la combinación de los descriptores "Coronavirus", "Lactation" y "Breastfeeding”. La limitación en cuanto al año de publicación de los artículos durante las búsquedas realizadas fue de 2019 a 2020. Resultados: la búsqueda en las fuentes de datos permitió la inclusión de diez artículos, dos de revistas brasileñas, encontradas en la base de datos LILACS, y ocho de origen internacional, seleccionados de la base de datos PubMed. Conclusión: a partir de esta revisión, se evidenció que la mayoría de los estudios abordaron la recomendación de mantener la práctica de la lactancia materna por parte de las mujeres con COVID-19. Estos estudios refuerzan la importancia de la consejería, los cuidados necesarios durante el acto de amamantar, además de reconocer los beneficios de amamantar. El gran número de investigaciones sobre el tema defiende y favorece la lactancia materna para mujeres con sospecha o diagnóstico de COVID-19, lo que limita la discusión con artículos similares.

Palabras clave: COVID-19; Coronavirus; Lactancia; Lactancia materna.

\section{Introduction}

The disease caused by the SARS-CoV-2 coronavirus, called COVID-19, presents a clinical picture that varies from asymptomatic infections to severe respiratory conditions (OMS, 2019; Ma et al., 2020). Due to the large number of patients infected by this new virus, the World Health Organization (WHO) declared a COVID-19 pandemic. With the advent of the pandemic, millions of people around the world became sick and millions more died. In Brazil, the Ministry of Health pointed 
Research, Society and Development, v. 11, n. 3, e20611326292, 2022

(CC BY 4.0) | ISSN 2525-3409 | DOI: http://dx.doi.org/10.33448/rsd-v11i3.26292

to an alarming mortality rate (Worldometer, 2020; Brasil, 2020).

In the context of the pandemic, because pregnant women are in a state of lower immunity, they are more susceptible to the virus (Wang et al., 2020). To date, there is a paucity of data on the repercussions of COVID-19 on pregnancy and on the transmission of its agent vertically, through breastfeeding. Breast milk offers protection against many diseases and is the best source of nutrition for most babies. There are rare contraindications to breastfeeding, just systematic screening recommendations for any suspected COVID-19 infection during pregnancy. Prolonged follow-up of the mother and fetus/baby is a recommendation if infection is present (Favre et al., 2020).

No data proves transmission of the COVID-19 virus through breast milk. (Rasmussen et al., 2020). In addition, considering that there is no scientific evidence on the presence of the new coronavirus in the breast milk of infected women, breastfeeding is an act that should be encouraged with caution and prudence. However, mothers diagnosed as a suspected or confirmed case should follow the recommendations related to breastfeeding and hand hygiene to avoid contamination of the baby (Chen et al., 2020).

Other information compiled by the United Nations Children's Fund (UNICEF) reveals that symptomatic mothers, as long as they are free from severe signs and symptoms and are willing, should wear N-95 masks to care for their baby (including while breastfeeding). Furthermore, if the mother is very sick, she should be encouraged to express the milk and offer it to the child through a clean cup and/or spoon, following the same methods of preventing contamination (FNUI, 2020).

It is therefore necessary that health professionals who care for breastfeeding women, including nurses, provide quality health care for a better offer of care for this woman affected by COVID-19. This attention should take place from the moment this woman seeks basic health care until her hospitalization and discharge. In any case, the successive investigation of the health needs of this clientele is of considerable importance, especially due to the clinical and epidemiological relevance of the disease and the scarcity of studies and reliable statistics on the relationship between COVID-19 and breastfeeding.

Given the importance of breastfeeding and the need for specialized and safe care for pregnant and postpartum women diagnosed or suspected of having COVID-19, the following guiding question arose: What are the general recommendations for the practice of breastfeeding in the face of infection by the new coronavirus?

Thus, considering the aforementioned aspects, the present study aimed to analyze the general recommendations for the practice of breastfeeding in the face of infection by the new coronavirus. This integrative review was relevant due to the survey of evidence available in the literature for the improvement and foundation of nursing practice in the context of breastfeeding. This study can contribute to improving the care provided to postpartum women diagnosed with or suspected of having COVID-19, with a view to publishing the synthesis and critical analysis of studies already produced on the subject.

\section{Methodology}

This is an integrative literature review, which aims to gather and synthesize research results on a given topic or issue in a systematic and orderly manner, contributing to the deepening of the knowledge of the investigated topic (Mendes et al., 2008). To carry out this integrative review, the authors first identified a research question. Then, the criteria for inclusion and exclusion of articles were established. The authors of the present study followed the following steps: sample selection by searching the databases, summarizing the information extracted from the selected articles, evaluating the studies, interpreting and discussing the results and, finally, presenting the review and knowledge synthesis (Mendes et al., 2008).

The guiding question of this study was the following: What are the general recommendations for the practice of breastfeeding in the face of infection with the new coronavirus? The construction of the question involved the acronym PICO (Brasil, 2012), being 'P' for population (postpartum women); Intervention 'I' (recommendations on breastfeeding in the time 
of COVID-19); Control 'C' (no terms were used for comparison); ' $O$ ' for outcomes (measures that should be taken to prevent transmission of the SARS-CoV-2 virus during care and breastfeeding).

The following databases included the data sources for this study: LILACS (Latin American and Caribbean Literature on Health Sciences) and PubMed (Public/Publish Medline). The inclusion criteria for the articles in the review were being an original, complete scientific research article, available free, and published in Portuguese, English or Spanish between the years 2019 and 2020, as well as answering the guiding question. We excluded repeated studies that did not meet the aforementioned criteria.

The controlled descriptors listed for searches in data sources are present in the MESH Terms (Medical Subject Headings) and DeCS (Health Sciences Descriptors). For the LILACS database, the following controlled descriptors in Portuguese were used "Coronavirus", "Lactação" and "Aleitamento Materno". For the MEDLINE database accessed by Pubmed, the controlled MESH descriptors were "Coronavirus", "Lactation" and "Breastfeeding". The crossing of the descriptors was performed in a unique combination using the Boolean operator AND.

The choice of descriptors is justified by the fact that the objective of this study was to seek evidence on safe recommendations for the practice of breastfeeding in the face of this COVID-19 pandemic scenario. The search took place through online access, from March to May 2020. The selected studies were organized, distributed and presented in a table in the results section.

For data collection, the study researchers used an instrument adapted from Bianchini et al. (2010). This instrument made it possible to describe the following characteristics of the articles: identification (article title, journal title, authors, country, language and year of publication), level of evidence based on Melnyk and Fineout-Overholt (2005), type of study, objective , methodology and categorization of themes, main results and conclusions and the databases where they were found. We categorized the evidence according to the type of breastfeeding practice recommendation: "breastfeeding is not recommended for mothers infected with SARS-CoV-2" and "breastfeeding is recommended for mothers infected with SARS-

CoV-2".

\section{Results}

The articles found with the searches carried out in the databases were submitted to exploratory, selective and analytical reading through which the inclusion criteria were applied. Thus, the final sample of this integrative review consisted of 10 articles (Table 1).

Table 1 - Selection process of scientific articles listed in this integrative literature review.

\begin{tabular}{c|ccc}
\hline & PubMed & LILACS & Total \\
\hline Production found & 61 & 380 & 441 \\
Non-original research article & - & 168 & 168 \\
Not published between 2019/2020 & 48 & 157 & 205 \\
Did not address the topic of study & 5 & 53 & 58 \\
Total selected & 8 & 2 & $\mathbf{1 0}$ \\
\hline
\end{tabular}

Source: Authors (2020).

Below, in Table 2, is the description of the summary of characteristics, level of evidence, objectives, results and conclusions of the studies. Of the ten articles selected, two are in Brazilian journals, in the LILACS database. In addition, eight articles were of international origin, two from China, two from the USA, one from Australia, one from Italy, one from Germany and another from the United Kingdom, all selected from the PubMed database. 
Research, Society and Development, v. 11, n. 3, e20611326292, 2022

(CC BY 4.0) | ISSN 2525-3409 | DOI: http://dx.doi.org/10.33448/rsd-v11i3.26292

All studies are from 2020. Regarding the type of methodology, seven studies were cross-sectional and exploratory, two were cohort and one was a case study. As for the level of evidence, six studies presented evidence level six, two studies presented evidence level five and the other two studies presented level four.

Table 2 - Presentation of the synthesis of articles included in the integrative review.

\begin{tabular}{|c|c|c|c|}
\hline Category & $\begin{array}{l}\text { Article, year, place, method, } \\
\text { Database and level of } \\
\text { evidence }\end{array}$ & Objective & Results and conclusions \\
\hline \multirow{9}{*}{ 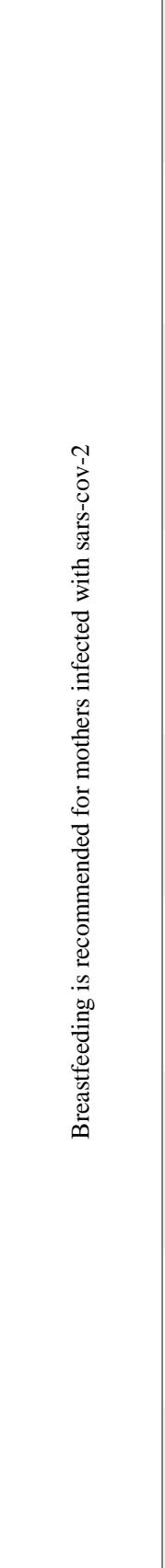 } & $\begin{array}{c}\text { Article } 1 \\
\text { (Chen et al., 2020) } \\
\text { China, Wuhan } \\
\text { Prospective Cohort Study } \\
\text { Level } 4\end{array}$ & $\begin{array}{l}\text { To assess the clinical features of } \\
\text { COVID-19 in pregnancy and the } \\
\text { potential for intrauterine vertical } \\
\text { transmission of COVID-19 } \\
\text { infection. }\end{array}$ & $\begin{array}{c}\text { Currently, there is no consolidated evidence of vertical } \\
\text { transmission: there was no proof that the virus was present } \\
\text { in the amniotic fluid, umbilical cord, oropharyngeal swab } \\
\text { of newborns and in the breast milk of } 9 \text { analyzed } \\
\text { puerperal women. }\end{array}$ \\
\hline & $\begin{array}{c}\text { Article } 2 \\
\text { (Ortiz et al, 2020) } \\
\text { Australia, Southport } \\
\text { Case Study } \\
\text { Level } 6\end{array}$ & $\begin{array}{l}\text { To report the case of an } \\
\text { uncomplicated vaginal delivery } \\
\text { in a SARS-CoV-2 positive } \\
\text { mother. }\end{array}$ & $\begin{array}{l}\text { One newborn underwent } 19 \text { tests within } 24 \text { hours of } \\
\text { delivery and all were negative for SARS-CoV- } 2 \text {. The } \\
\text { child continued on exclusive breastfeeding. }\end{array}$ \\
\hline & $\begin{array}{c}\text { Article } 3 \\
\text { (Davanzo et al., 2020) } \\
\text { Italy, Trieste } \\
\text { Exploratory and Descriptive } \\
\text { Study } \\
\text { Level } 6\end{array}$ & $\begin{array}{l}\text { Build measures for COVID-19 } \\
\text { infection control through the } \\
\text { promotion of breastfeeding and } \\
\text { the initial safe mother-infant } \\
\text { relationship after birth. }\end{array}$ & $\begin{array}{l}\text { Based on current scientific knowledge, breast milk from a } \\
\text { mother with COVID-19 is not a vehicle of transmission. It } \\
\text { is speculated that, similar to the SARS-CoV epidemic of } \\
2002-2003 \text {, antibodies specific for SARS-CoV-2 pass } \\
\text { through the COVID-19 mother's breast milk to the baby } \\
\text { within a few days of illness onset, possibly modulating the } \\
\text { clinical expression of the baby's infection. }\end{array}$ \\
\hline & $\begin{array}{l}\text { Article } 4 \\
\text { (Stumpfe et al., 2020) } \\
\text { Germany, Erlangen } \\
\text { Exploratory Study } \\
\text { Level } 5\end{array}$ & $\begin{array}{l}\text { Provide an overview of severe } \\
\text { acute respiratory syndrome } \\
\text { (SARS) novel coronavirus } 2 \\
\text { (SARS-CoV-2) and, in } \\
\text { particular, deduce potential risks } \\
\text { and complications for pregnant } \\
\text { patients from it. }\end{array}$ & $\begin{array}{c}\text { Given that no pathogen has been isolated from breast milk } \\
\text { in the tests performed, so far, transmission via } \\
\text { breastfeeding is unlikely. }\end{array}$ \\
\hline & $\begin{array}{l}\text { Article } 5 \\
\text { (Mullins et al., 2020) } \\
\text { UK, London } \\
\text { Exploratory Study } \\
\text { Level } 5\end{array}$ & $\begin{array}{l}\text { Guide health policy and } \\
\text { management of women } \\
\text { affected by COVID-19 during } \\
\text { pregnancy. }\end{array}$ & $\begin{array}{l}\text { There was no evidence of vertical transmission. Babies } \\
\text { born to mothers who are suspected/infected with COVID- } \\
19 \text { can receive breast milk. }\end{array}$ \\
\hline & $\begin{array}{c}\text { Article } 6 \\
\text { (Marinelli \& Lawrence, 2020) } \\
\text { USA, Connecticut Prospective } \\
\text { Cohort Study } \\
\text { Level } 4\end{array}$ & $\begin{array}{l}\text { To evaluate the effectiveness of } \\
\text { the use of antimicrobials in the } \\
\text { treatment of SARS-CoV-2. }\end{array}$ & $\begin{array}{l}\text { So far, the first and only report of six milk samples from } \\
\text { infected mothers in China has been negative. Mothers } \\
\text { with suspected, probable, or confirmed COVID-19 } \\
\text { infection should feed their babies according to standard } \\
\text { infant feeding guidelines, with appropriate precautions to } \\
\text { protect and control infections. }\end{array}$ \\
\hline & $\begin{array}{c}\text { Article } 7 \\
\text { (Diane, 2020) } \\
\text { United States, Philadelphia } \\
\text { Cross-sectional Study } \\
\text { Level } 6\end{array}$ & $\begin{array}{l}\text { Provide guidance on } \\
\text { breastfeeding and COVID-19 } \\
\text { and reaffirm why it is of } \\
\text { paramount importance to } \\
\text { promote and protect the use of } \\
\text { human milk and breastfeeding. }\end{array}$ & $\begin{array}{l}\text { Studies with women infected with the new coronavirus } \\
\text { did not reveal the presence of the virus in human milk. }\end{array}$ \\
\hline & $\begin{array}{c}\text { Article } 8 \\
\text { (Procianoy et al., 2020) } \\
\text { Brazil, Rio Grande do Sul } \\
\text { Exploratory Study } \\
\text { Level } 6\end{array}$ & $\begin{array}{l}\text { Reflect current knowledge about } \\
\text { neonatal and COVID-19. }\end{array}$ & $\begin{array}{l}\text { Due to the lack of evidence for mother-to-child } \\
\text { transmission, as well as for transmission through breast } \\
\text { milk, most scientific organizations recommend not } \\
\text { separating mothers and newborns, with the aim of } \\
\text { promoting breastfeeding and neonatal bonding. }\end{array}$ \\
\hline & $\begin{array}{c}\text { Article } 9 \\
\text { (Monteleone et al., 2020) } \\
\text { Brazil, São Paulo } \\
\text { Exploratory Study } \\
\text { Level } 6\end{array}$ & $\begin{array}{l}\text { Report and discuss current evidence } \\
\text { of COVID-19 infections during } \\
\text { pregnancy and their potential } \\
\text { consequences for assisted } \\
\text { reproduction care }\end{array}$ & $\begin{array}{l}\text { SARS-CoV-2 infections are similar to infections in women } \\
\text { with COVID-19 pneumonia. There is no evidence of vertical } \\
\text { transmission of SARS-CoV-2 in late pregnancy. }\end{array}$ \\
\hline 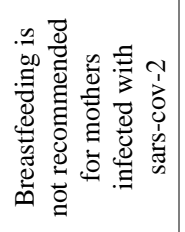 & $\begin{array}{c}\text { Article } 10 \\
\text { (Wang et al., 2020) } \\
\text { China, Wuhan } \\
\text { Exploratory and Descriptive } \\
\text { Study } \\
\text { Level } 6\end{array}$ & $\begin{array}{l}\text { To clarify the main doubts of } \\
\text { pregnant women amid the } \\
\text { pandemic. }\end{array}$ & $\begin{array}{l}\text { A case of SARS-CoV-2 infection with pharyngeal nucleic acid } \\
\text { swab virus occurred in a baby just } 36 \mathrm{~h} \text { after birth, and the } \\
\text { mother was a confirmed case of SARS-CoV-2. Therefore, } \\
\text { mother-to-child transmission of SARS-CoV-2 remains } \\
\text { unverified. Even so, these researchers do not recommend } \\
\text { breastfeeding in cases where the mother is suspected, infected, } \\
\text { or clinically uncured. }\end{array}$ \\
\hline
\end{tabular}




\section{Discussion}

All pregnant and lactating women should receive breastfeeding guidance. These mothers must obtain correct information/guidance from qualified and scientifically based professionals. From the acquisition of knowledge and quality information, this family will certainly have more security and empowerment necessary for the practice of breastfeeding.

Only the study by (Wang et al., 2020), a study of Chinese origin, contraindicates breastfeeding in suspected and confirmed cases. This evidence denotes the not ruled out possibility of vertical viral transmission, even in the absence of confirmed cases. An opinion issued in a consensus of Chinese experts is in favor of this evidence by stating that, in theory, the possibility of vertical transmission of COVID-19 could be real (Monteleone et al., 2020).

These specialists reinforce the importance of research that seeks to review the possibilities of transmission of the virus in breast milk. They also describe the need to screen for the presence of the new coronavirus in human milk from healthy donors. This is due to the possibility of the virus being present in the milk during the incubation period of the disease. However, there is no case of vertical transmission of the new Coronavirus (Monteleone et al., 2020).

Given the current context of the COVID-19 pandemic, most of the evidence from the review recommends maintaining breastfeeding, showing that breastfeeding is safe and indicated in cases of COVID-19. Of the articles that deny the vertical transmission of the new coronavirus, one of them was a clinical study with nine patients with pneumonia caused by COVID19. In six of them, the researchers investigated the presence of the virus in the amniotic fluid, umbilical cord blood, breast milk and swab from the newborn's oropharynx. All samples were negative.

Thus, there are no records of vertical transmission during pregnancy, nor in the neonatal period through breastfeeding (Chen et al., 2020). In Brazil, it was necessary to implement a recommendation with the Technical Note COVID-19 ${ }^{\circ}$ 12/2020, which contraindicated breastfeeding in suspected and confirmed cases (Brasil, 2020). However, sometime later, the country's Ministry of Health issued a new Technical Note, No. 7/2020, recommending the practice of breastfeeding by women with COVID-19 or suspected of having this disease (Brasil, 2020).

The separation of the mother and child in cases of contraindication to breastfeeding can have consequences for the adherence and maintenance of breastfeeding later. Therefore, it is important that this recommendation favorable to the practice of breastfeeding remains in force until there are more robust studies that prove the possibility of vertical transmission of the new variants of the disease.

The Royal College of Obstetricians and Gynecologists (RCOG) is very clear in advising that mothers and babies should be kept together and consequently questions the Chinese recommendation to routinely separate the newborn from the COVID-19 mother. According to the RCOG, the separation between mother and newborn must be justified by the mother's poor health status, need to perform therapies for the newborn, admission to an adult or neonatal ICU or both, etc. In cases that need to separate the binomial, this woman should receive support and guidance regarding the extraction and supply of human milk to her child (Ortiz et al., 2020).

Two reviews on the subject, one from the US Centers for Disease Control and Prevention (CDC) and the other from the London RCOG, emphasize that breastfeeding is important along with the necessary care. Among the necessary care is the use of a mask by the breastfeeding woman and hand washing before feedings (Ortiz et al., 2020; CDC, 2019). Therefore, except for any intercurrence that requires the separation of the binomial, such as, for example, the worsening of maternal health conditions, it is perfectly possible for mother and child to remain in a rooming-in system until hospital discharge (Ortiz et al., 2020).

Both publications stated that the benefits of breastfeeding outweigh any potential risks of transmitting the virus through breast milk. Thus, women with COVID-19 who wish to breastfeed should be encouraged to do so and take precautions 
Research, Society and Development, v. 11, n. 3, e20611326292, 2022

(CC BY 4.0) | ISSN 2525-3409 | DOI: http://dx.doi.org/10.33448/rsd-v11i3.26292

to prevent viral spread to the newborn and consider the possibility of requesting the help of someone who is healthy to offer milk breast milked to the baby. The lactating mother does not appear to transmit the virus through breast milk, either by breastfeeding or by offering milk expressed by a mother with confirmed/suspected COVID-19 (Stumpfe et al., 2020).

To guide mothers who wish to maintain breastfeeding during COVID-19 infection, Technical Note No. 15/2020, prepared by the Ministry of Health, recommends that they always wash their hands with soap and water and/or use gel alcohol to $70 \%$ on hands before touching the baby or before expressing breast milk. Wearing a mask during breastfeeding and avoiding talking during breastfeeding are also important recommendations (Vida, 2020).

For mothers who have a confirmed/suspected case and feel unable to breastfeed and who choose to pump breast milk, there are the following recommendations: wash your hands with soap and water and clean the pump after each use. Another important recommendation is to offer breast milk expressed with a clean cup and/or spoon, by the mother herself if she so wishes and is healthy enough to do so, or by a person who does not show signs or symptoms of illness and with whom the baby feels comfortable (OMS, 2020; SBP, 2020).

It is noteworthy that the extraction of breast milk, even during the disease period, is important to maintain milk production. This is because milking and/or sucking the baby favors the maintenance of production by lactating women, allowing mothers to breastfeed while they recover (Brasil, 2015).

The nurse is fundamental in the assistance and care of women with suspected or confirmed COVID-19. The results of this study also allow this professional to guide and outline their conduct correctly. Finally, this integrative literature review allows the incorporation of its results, which are scientific evidence, in clinical practice in a clear and understood way, based on the synthesis of the results of the research found. This contributes to deepening knowledge and improving the practice of breastfeeding in times of the COVID-19 pandemic.

There is a need for constant training of professionals who assist women, pregnant and postpartum women in relation to the practice of breastfeeding. This service must be carried out in a way that prioritizes dialogue, that is, qualified listening, promoting the empowerment of this clientele. The importance of the role of the health professional in this scenario is evident, as they have the vocation of health education and are responsible for counseling and guidance. These are the recommendations available until the day of the integrative review, so they are subject to review through new publications and scientific studies.

With this study, it is possible to identify the best recommendations on the practice of breastfeeding for mothers affected by COVID-19. In addition, the results of this study strengthen the knowledge of pregnant and postpartum women with true information about breastfeeding at the time of SARS-CoV-2 infection, contributing to the clarification of doubts. To date, few consistent studies linking COVID-19 and breastfeeding are available in scientific virtual libraries and databases; this is because current knowledge about coronavirus 2 (SARS-CoV-2) infection is limited. There have also been a small number of studies on the contraindication of breastfeeding in case the mother has COVID-19 (SARS-CoV-2).

\section{Final Considerations}

Most studies addressed the recommendation to maintain the practice of breastfeeding in women with COVID-19. These studies reinforce the importance of counseling, the necessary care during the act of breastfeeding, in addition to recognizing the benefits of breastfeeding. However, a chain of Chinese researchers contraindicates breastfeeding by infected or suspected COVID-19 mothers. The evidence available in the literature on COVID-19 and breastfeeding needs further investigation and discussion. Publications on this topic, as it is a new topic, are in continuous production, so it is essential to keep up with changes. The large number of research on the subject defends and favors breastfeeding for women suspected or diagnosed with COVID-19, which limits the discussion with similar articles. Therefore, it is suggested that researchers in the 
Research, Society and Development, v. 11, n. 3, e20611326292, 2022

(CC BY 4.0) | ISSN 2525-3409 | DOI: http://dx.doi.org/10.33448/rsd-v11i3.26292

area can focus on carrying out more robust experimental studies that can prove or not the possibility of transmission of the virus through breastfeeding and the most recommended recommendations to be taken from this evidence.

\section{References}

Bianchini, S. M., Galvão, C. M., Arcuri, E. A. M. (2009). Cuidado de enfermagem ao paciente com acidente vascular encefálico: revisão integrativa. Braz J Nurs, 9(2).

Brasil. (2012). Diretrizes metodológicas: elaboração de revisão sistemática e metanálise de ensaios clínicos randomizados. Ministério da Saúde: Brasília, DF.

Brasil. (2019). Painel de casos de doença pelo coronavírus 2019 (COVID-19). Ministério da Saúde: Brasília, DF.

Brasil. (2020). Recomendações para prevenção e controle de infecções pelo novo coronavírus (COVID-19) para Atenção à Gestante e Puérpera. Nota Técnica COVID-19 No 12/2020 SESA/SSAS/GROSS/NEAPRI-REMI. Ministério da Saúde: Governo do Estado do Espírito Santo.

Brasil. (2020). Secretaria de Atenção Primária à Saúde Departamento de Ações Programácas Estratégicas. Aleitamento e COVID-19. Nota Técnica nº 7/2020DAPES/SAPS/MS. Ministério da Saúde: DF.

BRASIL. Secretaria de Atenção à Saúde Departamento de Atenção Básica. Saúde da Criança: Nutrição Infantil Aleitamento Materno e Alimentação Complementar. $2^{\mathrm{a}}$ edição Cadernos de Atenção Básica, $\mathrm{n}^{\circ}$ 23. Ministério da Saúde: Brasília -DF, 2015.

Centers of Disease Control and Prevention (CDCP). Coronavirus disease 2019. Atlanta: CDC, 2019.

Chen, H., Guo, J., Wang, C., Luo, F., Yu, X., Zhang, W. \& Zhang, Y. (2020). Clinical characteristics and intrauterine vertical transmission potential of COVID-19 infection in nine pregnant women: a retrospective review of medical records. The lancet, 395(10226), 809-815.

Collins, P. (2020). Worldometers: real time world statistics. Worldometers. info. Dadax, 9.

Davanzo, R., Moro, G., Sandri, F., Agosti, M., Moretti, C., \& Mosca, F. (2020). Breastfeeding and coronavirus disease-2019: Ad interim indications of the Italian Society of Neonatology endorsed by the Union of European Neonatal \& Perinatal Societies. Maternal \& Child Nutrition, $16(3)$, e13010.

Diane L. S. (2020). The Association of Women's Health, Obstetric and Neonatal Nurses.Published by Elsevier Inc. University of Pennsylvania School of, Boulevard, Philadelphia.

Favre, G., Pomar, L., Qi, X., Nielsen-Saines, K., Musso, D., \& Baud, D. (2020). Guidelines for pregnant women with suspected SARS-CoV-2 infection. The Lancet Infectious Diseases, 20(6), 652-653.

Fundo das Nações Unidas para a Infância (2020). Coronavírus (COVID-19): O que os pais precisam saber.

Ma, K., Chen, T., Han, M. F., Guo, W., \& Ning, Q. (2020). Management and clinical thinking of Coronavirus Disease 2019. Zhonghua gan zang bing za zhi= Zhonghua ganzangbing zazhi. Chinese journal of hepatology, 28, e002-e002.

Marinelli, K. A., \& Lawrence, R. M. (2020). Safe handling of containers of expressed human milk in all settings during the SARS-CoV-2 (COVID-19) pandemic. Journal of Human Lactation, 36(3), 498-501.

Melnyk, B. M., \& Fineout-Overholt, E. (Eds.). (2011). Evidence-based practice in nursing \& healthcare: A guide to best practice. Lippincott Williams \& Wilkins.

Mendes, K. D. S., Silveira, R. C. D. C. P., \& Galvão, C. M. (2008). Integrative literature review: a research method to incorporate evidence in health care and nursing. Texto \& Contexto-Enfermagem, 17, 758-764.

Monteleone, P. A., Nakano, M., Lazar, V., Gomes, A. P., de Martin, H., \& Bonetti, T. C. (2020). A review of initial data on pregnancy during the COVID-19 outbreak: implications for assisted reproductive treatments. JBRA assisted reproduction, 24(2).

Mullins, E., Evans, D., Viner, R. M., O'Brien, P., \& Morris, E. (2020). Coronavirus in pregnancy and delivery: rapid review. Ultrasound in Obstetrics \& Gynecology, 55(5), 586-592.

Organização Mundial da Saúde (OMS). Prevenção e controle de infecção durante os cuidados de saúde em caso de suspeita de COVID-19: orientação provisória. Genebra: OMS, 2020.

Organização Mundial da Saúde. (2019). Situação de surto de doença por coronavírus (COVID-19). OMS

Ortiz, E. I., Herrera, E., \& De La Torre, A. (2020). Coronavirus (COVID 19) infection in pregnancy. Colombia Médica, 51(2).

Procianoy, R. S., Silveira, R. C., Manzoni, P., \& Sant'Anna, G. (2020). Neonatal COVID-19: little evidence and the need for more information. Jornal de pediatria, 96, 269-272.

Rasmussen, S. A., Smulian, J. C., Lednicky, J. A., Wen, T. S., \& Jamieson, D. J. (2020). Coronavirus disease 2019 (COVID-19) and pregnancy: what obstetricians need to know. American journal of obstetrics and gynecology, 222(5), 415-426.

Sociedade Brasileira de Pediatria (SBP). O aleitamento materno nos tempos de COVID-19! No. 9. São Paulo: Departamento Científico de Aleitamento Materno, 2020. 
Research, Society and Development, v. 11, n. 3, e20611326292, 2022

(CC BY 4.0) | ISSN 2525-3409 | DOI: http://dx.doi.org/10.33448/rsd-v11i3.26292

Stumpfe, F. M., Titzmann, A., Schneider, M. O., Stelzl, P., Kehl, S., Fasching, P. A. \& Ensser, A. (2020). SARS-CoV-2 infection in pregnancy-a review of the current literature and possible impact on maternal and neonatal outcome. Geburtshilfe und Frauenheilkunde, 80(04), 380-390.

Vida, C. G. D. C. NOTA TÉCNICA N 15/2020-COCAM/CGCIVI/DAPES/SAPS/MS. Ministério da Saúde, 2020.

Wang, L., Shi, Y., Xiao, T., Fu, J., Feng, X., Mu, D., \& Zhou, W. (2020). Working Committee on Perinatal and Neonatal Management for the Prevention and Control of the 2019 Novel Coronavirus Infection. Chinese expert consensus on the perinatal and neonatal management for the prevention and control of the 2019 novel coronavirus infection. Ann Transl Med, 8(3), 47-55.

Wang, S. S., Zhou, X., Lin, X. G., Liu, Y. Y., Wu, J. L., Sharifu, L. M., \& Feng, L. (2020). Experience of clinical management for pregnant women and newborns with novel coronavirus pneumonia in Tongji Hospital, China. Current medical science, 40(2), 285-289. 